\title{
Andino-Catholic Rituals in Automobile Bolivia: Bendiciones, Ch'allas and K'oas Performed by Drivers from Chuquisaca
}

\author{
Manuel Moser ${ }^{1,2}$ (D)
}

Received: 29 June 2021 / Accepted: 13 August 2021 / Published online: 20 September 2021

(c) The Author(s) 2021

\begin{abstract}
In the article, I explore different motorcar blessing rituals undertaken by drivers from the Bolivian region of Chuquisaca, while centering primary my description on the side of the doing of the rituals and only linking them on a second stage to individual meaning and theological reflections. In that way, I show that the interviewed drivers differentiate the performed rituals first of all by their components (and not by their addressees) and consider all three of them as necessary parts of Catholic faith regardless of the positioning of the clerics. The interviewed drivers attribute effects of safe driving and economic successes to the rituals, but also experience them as partly linked to accidents and incidents and by consequence increase in the aftermath of misfortunes their ritual offerings. Therefore, I conclude that drivers of automobile Bolivia through the performed rituals are reproducing a social system of reciprocity that goes beyond human counterparts and that religious synthesis in their reflections is to be understood as a reaction from below (rather than a cause) to anti-syncretistic discourses amid religious elites.
\end{abstract}

Keywords Ritual $\cdot$ Automobility $\cdot$ Syncretism $\cdot$ Bolivia $\cdot$ Ethnography

\section{Resumen}

En el presente artículo se exploran rituales que choferes de la región boliviana de Chuquisaca emprenden para bendecir sus coches motorizados. Enmarcando primero el enfoque en los procesos del hacer de los diferentes rituales, estos solo se vincularán en un segundo momento a cuestiones de significado personal y reflexiones teológicas. De tal manera se demuestra que los choferes entrevistados diferencian los rituales celebrados en primera instancia por sus componentes (y no por sus destinatarios) y consideran a los tres rituales como partes necesarias de la fe católica, sin preocuparse por el posicionamiento de los clérigos. Los choferes entrevistados atribuyen tanto efectos de conducción segura como éxitos económicos a los rituales, pero también los experimentan como vinculados en parte a accidentes e incidentes $y$, por consiguiente,

Manuel Moser

manuel.moser@uni-erfurt.de

1 Department of Religious Studies, University of Graz, Graz, Austria

2 Max Weber Centre for Advanced Cultural and Social Studies, University of Erfurt, Erfurt, Germany 
aumentan sus ofrendas después de haber sufrido infortunios. Por lo tanto, concluyo que los choferes a través de los rituales realizados están reproduciendo un sistema social de reciprocidad que va más allá de contrapartes únicamente humanas, y que la síntesis religiosa en sus reflexiones debe entenderse como una reacción desde abajo (en lugar de una causa) a discursos anti-sincretistas mantenidos por élites religiosas.

Palabras clave Ritual $\cdot$ Automovilidad $\cdot$ Sincretismo $\cdot$ Bolivia $\cdot$ Etnografía

\section{Resumo}

Este artigo explora rituais que motoristas da região boliviana de Chuquisaca realizam para abençoar seus automóveis. Foca-se, primeiramente, sobre o fazerdos diferentes rituais, os quais apenas num segundo momento serão ligados a questões de significado pessoal e a reflexões teológicas. Mostra-se, desse modo, que os motoristasentrevistados diferenciam os rituais celebrados, em primeira instância, pelos seus componentes (e não pelos destinatários) e consideram os três rituais como partesnecessárias da fé católica, sem se preocupar com a posição dos clérigos. Os motoristas entrevistados atribuem segurança ao dirigir e sucesso econômico aos rituais, mas tambémos percebem como ligados, em parte, a acidentes e incidentes e, consequentemente, aumentam sua doação após infortúnios. Concluo, portanto, que os condutores, através dosrituais realizados, estão reproduzindo um sistema social de reciprocidade que vai além das contrapartes unicamente humanas, e que a síntese religiosa em suas reflexões deve serentendida como uma reação desde baixo (e não uma causa) aos discursos antissincréticos mantidos pelas elites religiosas.

\section{Palavras-chave Ritual $\cdot$ Automobilidade $\cdot$ Sincretismo $\cdot$ Bolívia $\cdot$ Etnografia}

We were going around riding on animals. Today there are almost none left, now everything is only with cars. But the customs are not getting lost, only these horses that were around.

$S^{*}, 69$ years old at the time of our conversation in 2017 and a farmer in rural Chuquisaca for all his life, identifies as a modern man. Himself a native Quechua speaker without any school education, he sometimes struggles to find words in Spanish; however, he raised all his seven children monolingually in Spanish, according to him in order to not disadvantage them while filling their heads with useless old knowledge. ${ }^{1}$ Modern into his old days, $\mathrm{S}^{*}$ recently bought his first car, a brandnew pickup truck which he cannot drive himself (contrary to the horse that he still owns) but which he uses several times per week to travel between his fields in Peñaderias and his secondary house in the small town of Monteagudo (with one of his

\footnotetext{
${ }^{1}$ Somehow ironically, in contemporary Bolivia knowledge of indigenous languages brings important advantages on the professional labor market, especially in government-related sectors. Because of the limited extend of this article, however, practices of negotiating identities of modernity will only be further touched on with regard to automobility. For more insights into the complexity of entangling modernity and religion consult, e.g. the case study of Mostowlansky (2017) amid roadside communities of the Pamir Highway.
} 
sons or grandsons driving). Acquiring his pickup truck, he immediately engaged a professional healer (curandero) to perform some rituals on the car, because "we always want nothing to happen to us, that we are protected by the Virgin. We have to do it always".

In this article, I will analyze car blessing rituals in Bolivia of the twenty-first century and discuss what contemporary car blessings in Bolivia look like and what motivates the drivers to perform them. Furthermore, I want to explore to what extend the car blessing rituals can be classified as andino-catholic syncretism. To answer these questions, I will work with empirical data from a three-month fieldwork in 2017 which included participatory observations during three different car blessing ceremonies performed by Catholic clerics, traditional healers, or the drivers themselves and eleven semi-structured interviews with Chuquisaquean drivers. ${ }^{2}$ In choosing my informants, I tried to cover a diversity of different identarian and professional backgrounds. Some of my interview partners lived in cities, some in rural areas. $\mathrm{S}^{*}$ was my oldest interview partner and $\mathrm{G}^{*}, 30$ years old, my youngest. I interviewed professional drivers, $\mathrm{F}^{*}$, a taxi-driver (and former long-distance trucker), and $\mathrm{R}^{*}$, a driver of a public minibus, and $\mathrm{T}^{*}$, an automobile mechanic. The remaining four were non-professional drivers, among them were $\mathrm{S}^{*}$ and $\mathrm{M}^{*}$, both pickup truck owners; $A^{*}$, a compact car driver; and $\mathrm{G}^{*}$, a motorcyclist. Unfortunately, my attempts to recruit a female driver as an interview partner failed, maybe because they are still a small minority on Bolivian roads. To complement my data and include a voice from the perspective of the Catholic Church, I interviewed the Chilean theologian and Franciscan friar $\mathrm{H}^{*}$, who worked in Bolivia for ten years.

In the first subsection, I will discuss the importance of automobility for a modernization paradigm and the hybridization of car and driver into a single unit. In the second subsection, I will present the different car blessing rituals performed by the interviewed drivers while putting (as a reflection of their narrations) emphasis on the side of the processes of doing the rituals, especially on the question which materials they use in the rituals. Only afterwards, in the third subsection, following the reflections of my interviewees, I try to explore their motivations for doing the rituals and what they mean to them. In the last subsection, I will discuss the question of syncretism while concluding that the drivers' religious synthesis is first of all a consequence of anti-syncretistic discourses.

\section{Automobility in Bolivia}

The mobility turn brought more awareness of movement(s) into the social sciences which for a long time had centered their main attention on rather static groupings of people and concepts. ${ }^{3}$ One of the core actors to be studied under the new paradigm was the automobile and its place in human society: Going beyond historical studies

\footnotetext{
${ }^{2}$ I parceled the three shortest interviews out and continued to work with the other eight, which I transcribed and coded following a simplified version of open coding according to grounded theory (Glaser and Strauss 2009).
}

${ }^{3}$ For an overview to mobilities research consult Adey et al. (2014). 
(e.g. Sachs 1992), which focused either on the aspect of car production in factories or on the environmental externalities of car use (its influence on atmospheric pollution and changes in urban landscapes, e.g. Nigam 2011), John Urry (2000) identified new additional factors that make the automobile the outstanding figure it is in our contemporary societies, which include the anthropomorphizing consumption of the car by individuals, its technical and social entanglements to non-automobile markets and its cultural framing in discourses about the good life (Urry 2000, p. 58). Assuming a global omnipresence of the car, Urry therefore classifies automobility as an autopoietic system:

Automobility can be conceptualized as a self-organizing autopoietic, nonlinear system that spreads world-wide, and includes cars, car-drivers, roads, petroleum supplies and many novel objects, technologies and signs (Urry 2004, p. 27).

Other scholars challenged Urry's classification of automobility as a system, arguing that we should rather speak of regimes, because the notion of system obscures power in the relationality between human and non-human entities that uphold automobility (Böhm et al. 2006). However, whether automobility is a system or automobilities are regimes, all these meta-narrations fail to analyze the day-to-day reality of life with a car. Until this day, rather few ethnographical studies have been made about what Daniel Miller (2001) called the "humanity of the car", the role of the car in non-Western societies and lower socio-economical classes is rarely addressed and even more rarely scholars acknowledge car cultures linked to religion. ${ }^{4}$

The mechanics and the basic look of cars around the world in the twenty-first century might not differ from each other as they used to, but there is no homogeneous global car culture. The automobile always acquiesces its humanity through localities and all local car cultures go beyond individuals' ideologies, but entangle with other cultural entities and concepts that have an importance for local collectives. In the case of my research, as I will argue, amid others there is an entanglement of cars with the cosmovision of andino-catholic syncretism. An overview of the history of the car in South America was written by Guillermo Giucci (2012), who argues that the car in South America is intrinsically linked to a vision (or a myth) of modernization. While Bolivians often complain about what they perceive as their country's backwardness compared to the neighboring countries of Chile, Argentina and Brazil, which continue constituting as main destinations for many temporary and long-term working emigrants (Rockefeller 2010; Ryburn 2018), the car is for many contemporary Bolivians the epitome of modern objects (Lefebvre 1971, p. 100). The current restriction to import automobiles older than one, three or five years (according to their type) into Bolivia is more often understood as a program to ensure the pride of the Bolivian nation, which nowadays is modern itself and does not have to rely on waste products from so-called developed countries, than it is understood as a program that envisions to protect the environment and drivers by reducing the influx of unsustainable and unsafe old cars. The important

\footnotetext{
4 Some notable exceptions are Elias (2011) working on Pakistani Islamic truck art and Upton (2016) investigating Christian identities amid US-American truck drivers.
} 
role of the car in the Andean myth of modernity is exemplified by the synonymic use of car and mobility [movilidad] in Bolivian Spanish.

Driver and car are closely entangled to a degree that some perceive in the car an extension of the human body (McLuhan 1994, pp. 217-225), a perception that is challenged in mobilities studies because of its technical determinism. Tim Dant (2004), while acknowledging that car and driver inter-influence each other, refuses notions as hybrids or cyborgs, but classifies the driver-car as assemblage of human and car into a temporally restricted unit. This (at least temporal) merging of human and non-human bodies is also experienced by Bolivian drivers, as $\mathrm{F}^{*}$, nowadays a self-employed taxidriver, reveals when answering my question whether he also performed blessing rituals on the heavy goods truck he drove before:

The owners, they only do the blessing of the mobilities. When I was travelling with the truck [on the transport corridors from the highlands] to Santa Cruz, only the owners did the blessings. Because I was part of the mobility, they also called me, I accompanied them. When I was working on this [truck]: Come, $\mathrm{F}^{*}$, we are going to do a blessing, they told me. I went because I was also a part of the mobility.

Interestingly, $\mathrm{F}^{*}$, even though he participated in a very similar manner in the festivities around the truck he used to drive as he does nowadays, he only started perceiving himself as an active ritual agent on the day he performed them on his own car. There is no huge difference in his ritual practices done the ritual, which I describe hereafter; however, the difference lies in the role he understands himself as having in the ritual. Being a truck driver, $\mathrm{F}^{*}$ was intrinsically linked to the automobile and while doing the libations and drinking alcohol (explained further in the next chapter) he experienced himself as a recipient part of the truck's body, while nowadays he experiences more possibilities to disentangle himself from the car for the time of the ritual and taking on a sovereign providing role in the ritual.

\section{Entangled Rituals}

There are many case studies about rituals in the Andes ${ }^{5}$, however, rather few discuss them in modern and urban contexts. One such example is the work done by Cecilie Vindal Ødegaard (2011) who analyzes ritual behavior in the population of an Arequipian suburb, and argues that rural migrants employ religious rituals "to make places out of [urban] spaces" (Ødegaard 2011, p. 352). Even though she sees the main motivation for these place-making practices in attaining prosperity, Ødegaard is well aware of the dangers her informants are experiencing when not engaging with their spatial surroundings in the so identified place-making processes. I myself would therefore question her translation of the witnessed activities as place-making processes, as this assumes an optionality that differs from what is experienced by many people in the Andes as a necessary interrelating and communicating with their surroundings in order to live and continue to live. Because of the ontological

\footnotetext{
5 Amid them Allen (2012), Bastien (1985), Gose (1994), Mayer (2004), Platt (2016), Sallnow (1987) and Taussig (2010).
} 
realities of the powers in the Andean landscape, Marisol de la Cadena (2015) discusses but disregards the notion of religion for describing communication processes between human (runakuna) and earth (tirakuna) beings in rural Cuzco, because according to her this would undermine the local ontologies. In regard to the notion of religion (and only in this regard), her work, as well as many case studies before hers, has the weakness that it starts with rather static and close (and many times centered around immaterial belief $[s]$ ) definitions of religion, which make it more complicated to aim for a good understanding of the local ritual practices. I tried to undertake a different path in my own fieldwork, which shall also be reflected in the structure of this article. First, I concentrated exclusively on the doing of different rituals I recognized in Bolivia, spoke with drivers about how they are performed and participated in them wherever possible. Only in a second stage did I try to understand the background why these rituals are done and discussed with my informants how they might link to systems of religion(s).

When starting my fieldwork in Bolivia in January 2017, many friends I knew from my childhood and adolescence in Cochabamba and Sucre advised me to go on a pilgrimage to Copacabana at the shores of the Lake Titicaca in order to investigate motorcar blessings. Therefore, I borrowed a car and prepared to drive to Copacabana for the festivities for the Virgen de la Candelaria. Investigating the relationship between (US-)American Catholicism and car culture, Peter S. Cajka (2010) argues that one important aspect of their intermingling during the twentieth century is found in the popularity of motorized pilgrimages to out-of-town shrines, which consequently undergo a process of modernization to better welcome automobile pilgrims. However, while exploring the religious studies literature about Copacabana, ${ }^{6}$ I was surprised not to find any work dedicated to the automobile pilgrimages and the very visible presence of masses of automobiles of all sizes in the small town, queuing for hours around the central streets to reach the front of the church, where a Catholic monk performed blessings.

In the afternoon of the $2^{\text {nd }}$ of February 2017, I decided to put the knowledge about the rituals that I gathered through observation to work and prepared the borrowed car to have it blessed. I washed the car clean from road dust and decorated it with arrangements of real as well as plastic flowers and festoons, a paper hut and a foam rubber tie, which I bought at the market stands in front of the church dedicated to sell everything needed for the blessings. While I was waiting with the decorated car in the automobile queue, people praised the decoration of $m y$ car and the fact that I, a foreigner, do also know the importance of blessings and I was asked if I would consider becoming godfather of another car, which would have meant to contribute financially to its decorating. I refused the honor and we laughed together.

The sequence of the blessing begins with a Catholic friar engaging together with the car pilgrims and companions in silent prayer in front of the open engine hood. This is followed by sprinkling holy water from a plastic bucket on the cylinder block and on additional objects (statuettes, icons, crucifixes, rosaries, sun blinds, fake

\footnotetext{
6 The most influential work was produced by Salles-Reese (1997) who rewrites the history of Copacabana following a phenomenological approach to religion.
} 
money and alasitas $^{7}$ ) laid on the engine or arranged in front of the car. Thereafter, the friar goes around the car to sprinkle from all sides holy water into the inside of the car, while finally sprinkling the pilgrim's family and posing for a memory photo taken by the pilgrims themselves on a mobile phone and/or by a professional photographer offering his services to all pilgrims. The part of the ritual engaging Catholic clerics (called bendición) ends with the pilgrims thanking the friar and handing him a slip of paper with a personal wish and some money as payment for his services. While acquiring the tools to get the car blessed (as described in the last paragraph), however, I was informed that I also need firecrackers and alcohol to complete the blessing but I was also told that I will have to wait until the cleric was out of sight in order to complete the blessing ceremony myself. I learned that the second part of the ritual consisted of what is called a ch'alla, sometimes including the burning of an offering called k'oa. While the ch'alla completes a bendición at a sanctuary, it is also performed on many other occasions throughout the year, most importantly on the Tuesdays of the Carnivals' week.

While for many drivers I interviewed there is no separation in the meaning of the different rituals, most of the drivers distinguish them by the ingredients involved in the blessing and by naming them differently (bendición and ch'alla). However, the distinction by name gets dropped in certain occasions, as for example by the mechanic $\mathrm{T}^{*}$ trying to explain to me why the clerics cannot be present at the ch'alla:

The priests or clerics [los sacerdotes o los curitas], they are, how can I explain it to you, they are doing the church service [misa], you see? [They are] the ones who are doing or presiding the church service [misa], [they] bring forward the church service [misa]. The clerics [curitas] are not, not, not, not [fourfold negation] at the ch'alla. But they are going to do the bendicion of the trucks, the cars, the pickup trucks. They are going to do the bendición and we are waiting until they wet [ellos mojen] the mobility with holy water [agua bendita]. And we are waiting until they do their ch'alla and only thereafter do we share, do we also do the ch'alla and the k'oa.

Before exploring these processes of entangling and disentangling of the different blessing rituals in more detail, I shall provide a presentation of the performance of the ch'alla and k'oa, as I explored them together with the taxi driver $\mathrm{F}^{*}$ and the mechanic $\mathrm{T}^{*}$, who invited me to take part in their Carnival's ch'allas. I appreciated their invitations as acts of trust and respect, as many drivers at first rejected to even discuss the practices with me because engaging in counter-rituals I could use the personal information obtained from them to cause them harm. The invitation to perform a ch'alla together was therefore particular risky for the two drivers as it put me in a situation where I might directly influence the outcome of their life-sustaining rituals by redirecting their offerings in bad ways. In order to avoid unwelcomed human and more-than-human beings at his ch'alla, $\mathrm{F}^{*}$ bought the ingredients the

\footnotetext{
7 Alasitas are miniatures that are bought and blessed in expectation of a (hoped for) acquisition of an object of desire. Alasitas exist for any conceivable object of desire, popular items ranging from cars to houses to mobile phones to business stores to kitchen utensils to high school and university diplomas to US green cards and passports of different nationalities to flight tickets, et cetera, et cetera.
} 
night before and we got up at half past four to light the fire and decorate (enflower) his taxi with balloons and festoons. Before further discussing the dangers linked to the rituals in the next subsection, I should present their sequence first:

$\mathrm{F}^{*}$ was not really sure what the table/plate [mesa] of the offering contained; however, each year he bought the $k$ 'oa from the same specialized market vendor, who he knows does a good job while preparing a personalized offering taking into consideration details of his car's make and his use of it as a shared taxi. The core elements of the k'oa are figurines with different motives for health, money, luck and others, which his favorite vendor [casera] knows to combine in an optimal way according to $\mathrm{F}^{*}$ 's current situation. We waited until the coal was hot glowing, while $\mathrm{F}^{*}$ informed me that the right temperature was particularly important, because in case the $k$ 'oa caught fire or got extinct he would suffer bad luck the following year. When putting the k'oa into the embers, an intense smelling smoke of frankincense, spices, fat, sugar and plastic, all burned together, developed instantly. $\mathrm{F}^{*}$ taught me to do libations with different alcoholic beverages in a clockwise rotation around the smoky $k^{\prime} o a$, before drinking ourselves some mouthfuls. Then, $\mathrm{F}^{*}$ walked around his taxi holding the smoky k'oa under it from all sides, ending the round in positioning the tray with the k'oa under the engine block. He repeated the round several times, in between we sprayed beer on the car, starting from the backside to the front because the car should be moving forward, and sat together drinking beer, chewing coca and smoking cigarettes waiting for the k'oa to consume itself well, while it started to become day. The k'oa had to persist under the engine until noon that day, in order for the taxi to absorb the smoke well, only thereafter the blessing of the ch'alla was complete. $\mathrm{F}^{*}$ dug a hole in his garden where he buried the ashes of the $k^{\prime}$ oa next to a tree and the car could be moved again.

Even though generally fast in admitting that they "of course" do ch'allas ("everybody, almost everybody does them"), most of my interview partners felt (at least at first) rather uncomfortable explaining to me how they are doing them, explaining they are only drivers, not ritual specialists as clerics [curas] and healers [curanderos]. An elderly Potosinian minibus driver I befriended in Copacabana even attributed his (experienced) limited knowledge about car blessings to the fact that he does not really know how an engine works, recommending me to talk to a mechanic (what I did thereafter). $\mathrm{R}^{*}$, a Chuquisaquean minibus driver, agreed fast to reflect on the performance of the ritual:

I: Could you comment on how a ch'alla is done? Because they do not know there [in my homeland], they do not know how it is.

$\mathrm{R}^{*}$ : Sure. To do a ch'alla we use elements. The elements we use to do a ch'alla, you first buy a k'oa, frankincense, everything taken of the Earth, everything produced by the Earth. [You buy] a k'oa, frankincense, some extracts from animal fat, from some animal, it can be a llama, its fat. And confetti, cut into small pieces, these confetti have the meaning of purity, ${ }^{8}$ [they are] white. These are the confetti. Coca, cigarettes, alcohol, singani, wine, these are

\footnotetext{
${ }^{8}$ Interestingly in Bolivian Spanish the word for confetti is mistura, which literary would be translated as mixture.
} 
used. These are the things. These are the elements you buy, you acquire to do a ch'allita. And you prepare the coal, the fire. When the coal, when it is nicely red, you pick everything up that you bought in a paper and your intention why you are doing the ch'alla, you pick everything up. When you want to do a ch'alla on a garage, you pick and buy figurines, there are figurines, I do not know, of a motor, of a mechanic with his tools, these things you prepare. And if I am a transporter and I want to do a ch'alla on my bus, I buy a van, a minibus in a figurine, the driver, his key, these things. When the fire is [ready], I prepare well, I chew coca, I smoke a cigarette and I pick up all these elements, I pick them all up and put them into the fire.

In addition to the plate of offerings of the k'oa and its figurines, key ingredients of the ch'alla are the coca leaves, the cigarettes and last but not least alcoholic beverages. The term alcohol mostly refers to the inexpensive nationally produced alcohol of sugar cane branded caiman containing $96 \%$ percent alcohol, which is marketed in plastic bottles or tin canisters of up to $10 \mathrm{~L}$. However, drivers normally buy small bottles for their ch'allas, which were rebottled by market vendors and sometimes softened by adding water. Singani is a more expensive national liquor, which is produced of distilled grapes and similar (but not equal) in its taste to the Chilean and Peruvian Pisco or the Italian Grappa. Singani, as well as local wine, is produced in the South Bolivian province of Tarija. Many cigarettes are rolled by market vendors from local unbranded tobacco, traded in major quantities. Coca leaves too are sold out of big bags on the market; many drivers buy them in pound units and use them not only in ch'allas but also as "snacks" on their trips to compete tiredness at the wheel and high-altitude problems. While the drivers understand the divine/worldly addresses to aliment themselves on the offered things, it is also crucial for them to ensure the connectivity of themselves personally to the offerings. This connection is established mainly by drinking alcoholic beverages in a collective way together with the divine/worldly entities (through libations), as explains $\mathrm{T}^{*}$, the mechanic:

[One does] the ch'alla with the three cups, you see? With the three bottles of wine, and the other of singani and alcohol, a ch'alla at the four angles of the k'oa. And drinking, sharing with Him Himself. Afterwards throw it on the ground. That's it. Others do it in a different form, right? I do not know about that, but my mother told me it is that way. And I do it that way. And afterwards, chewing some coca, smoking a cigar[ette], sharing with Her and repeating the ch'alla [with the three cups]. And well, then you must drink some shots of hard liquor. Maybe not exceed yourself, but [continue drinking] until the k'oa is finished. Don't move. Be in control that it [the k'oa] does not burn. And they tell you, if it burns it is because you will suffer. And if you are there controlling that it consumes itself well, you will be fine the [next] year. Therefore, one has to attempt to be there, [to] control and [to] request in good faith. To tell Him, yes, Lord, we need work here and the work is coming.

The ch'alla always is a risky transaction, as it could go wrong and many drivers fear consequences from economic losses to sometimes deadly accidents (more on 
this in the next subsection). Counterintuitively for Western thinking, taking attentive control of the ritual and managing the risks includes mandatory drinking to bring oneself closer to the divine/worldly addressees. One risk is the possibility of the $k$ 'oa enflaming instead of fuming, which could be linked to the paper elements used in the $k^{\prime} o a$, such as the fake money, and the necessity to offer some k'oas together with the newspaper page that they are bought on (for example the one destined to garages). However, the drivers do not experience the inflammation as being caused by the flammability of the ingredients of the $k$ 'oa, but by their misbehavior while directing the rituals. Therefore, many drivers, as for example $\mathrm{S}^{*}$ and $\mathrm{M}^{*}$, in order to prevent these risks of ritualistic misbehavior, employ professional healers to perform the ch'allas in their names. However, this can also be risky, as these curanderos might perform the blessings in unintentionally or deliberately bad ways, for example if they are double agents cooperating with somebody else who is envious of the driver's successes:

Here in Bolivia, you can expect everything from the people who want to harm you. Anything can be waiting for you. [...] They [curanderos] told me [consulted after a serious car accident], you have been cured [cursed by/with the help of a curandero], that is what they told me. But sometimes, how can I say this, one should doubt also the people from the medical camp, I would say so.

I: Afterwards, however, you got yourself cured?

I got myself cured, yes, I got myself cured. Truly, one has to have belief and faith in the medical camps. Another time too, I crossed [in the car] the waters of this river here [Río Chaco Bañado]. And I got stuck in the mud, and the waves of the high water were coming like this. I was crossing well, when suddenly mud came in and what did I do? I jumped into the water [to avoid the risk of being carried away in the floods with the car]. And I was having a cellphone with me, new shorts and money 250 [Bs.], fortunately it was folded, I did have it as a small roll in my shorts. I [was] stopped again, again [I/the car was] stuck in the mud, again [I jumped out] swimming. And this week I was complaining a lot, bored, after nothing I was complaining and I did get myself cured and I returned again to normality.

On the one hand, the interview extract (with $\mathrm{M}^{*}$, pickup truck driver and mine worker) shows that one reason to perform the blessings is to react to (potential) curses that different living and/or dead, human and/or territorial beings ${ }^{9}$ could have exercised on the drivers. However, during the interview, $\mathbf{M}^{*}$ seemingly changed several times his attitude towards the ritual specialists, who he referred to as medical camps [campos médicos]. Following up on what he was telling me, I posed questions to keep the interview running and hoping that they would facilitate my understanding of his motivations to do the rituals despite his doubts. Differently to what I expected, he did not comment on what I perceived as a discrepancy and what some

\footnotetext{
9 "Sometimes when you pass by, on a street, you always want to crash yourself over this [particular] cliff, as if something is pulling you. This happened to me. I: And you got yourself also cured from this? Yes, I got myself cured".
} 
of my questions, as the one above, were aiming at. Reading between the lines of M*'s words, I therefore understand his doubts to be limited to the benevolence of his human and superhuman surroundings and to a certain degree the proficiency of ritual specialists as link makers. However, he seems not to doubt the reality of communication processes that go beyond human partners. The traits of these communications shall be explored in the next subsection.

\section{Reciprocities Beyond Humans}

Many studies about community in the Andes identify the key of relationality in the Andean societies in the principle of reciprocity. Reciprocity can be understood as socioeconomical relations established and performed through practices of gift-giving (and taking). ${ }^{10}$ For example, acquiring helping hands at seeding and harvesting fields, managing animal herds or constructing houses does not necessarily involve monetary transactions, but is first of all linked to favors that are to be returned at a later stage. Therefore, the one first enrolling in such a project (e.g. construction of a house) is in a minor power position in regard to their (new) helpers because they do not know when and how they will be able to balance the transactions out again and until then the asymmetrical situation gives their helpers influence over them. Focusing primarily on interhuman relations, academic discourses, however, always considered reciprocity to include, to a certain degree, divine (territorialized and deterritorialized) addressees as well, which are for the Andean societies not disconnected from the mundane world to a degree as philosophers and theologians of transcendence assume, but which act in human-like (reciprocal) ways in the same socio-economical spheres where humans intermingle with each other. Contemporary researchers strengthen these approaches, while they, following the so-called material turn, pay even more attention to the materials themselves and how they engage with humans. Catherine Allen (2016) explores how living stones [inqaychu] infused with power by mountains interact in reciprocal rituals with animal herds and their herders. Differing from her previous work (Allen 2012) she concludes that the discussed stones go beyond being mere representations of other beings, but act by themselves:

The word "representing" is problematic because it implies an iconic (i.e., metaphoric) relationship of one-to-one resemblance between the stones and domestic animals. From a herder's perspective, however, the inqaychu operates according to an entirely different mode of signification. An inqaychu doesn't represent anything; it presents itself. [...]. Recognizing the personhood of places and stones (as we must in this context) entails shifting our terms of analysis to presentation rather than representation, and to predication rather

\footnotetext{
10 Although building on many ethnographical studies, Marcel Mauss (2002) did not include in his analysis of gifts examples from South America. Nevertheless, many anthropologists refer to him when explaining the system of Andean economics, e.g. Alberti and Mayer (1974), Ferraro (2004). For more references consult also the works quoted in footnote 6 .
} 
than symbolism [parentheses and quotation marks by C.A.] (Allen 2016, p. 340).

However, Allen identifies that contemporary Andean farmers are abandoning to engage in reciprocal relations with living stones. She blames these "deep and rapid" transformations ${ }^{11}$ to be the consequence of her informants not relying to the same degree on herds of llamas and alpacas to generate their economical income, but nowadays counting with additional sources of income, especially from tourism. Allen is by no means the first to describe, neither to predict the (immediate) end of rituals of reciprocity in Andean societies, many ethnographic case studies described similar scenarios before her, blaming different processes and entities to be the cause of the eye-witnessed disappearance of rituals. Just to mention some explanations, Ina Rösing (2001, p. 66) saw urbanization and development cooperation at the root of their disappearance, Fernando Montes Ruiz (1999, p. 406) blamed the State and programs of literacy and Joseph Bastien (1985, p. 33) identified a symptom of the cultural ruin in the use of a motorized truck to ship the collected wool to the market. The authors witnessing and predicting the disappearance of reciprocal rituality in the Andes are not limited to modern centuries, but similar arguments can already be found in colonial times as for example in the historiography of the Virgin of Copacabana narrated by Alonso Ramos Gavilán (1621) at the beginning of the seventeenth century:

In the year $1618 \mathrm{I}$ noted in Copacabana a curiosity and old nonsense [antigualla] that continues until today amid some persons and that they had taken from the incas. [...] I saw that while all the people were together on a patio, a long procession of Indians entered, young men and women [muchachos y muchachas] and every one of them brought in their hands some gift, and everything was put in a chamber. [...] As I was seeing this curiosity [...] the Indians told me, Father, we are not doing this because of a rite or a ceremony but because this couple shall have everything necessary and serve God better not lacking anything (Ramos Gavilán 1621, pp. 118-119, transl. by me).

Ramos Gavilán, although sometimes appreciated as a premodern ethnographer (Lazcano González 2017, p. 254; van den Berg 2015, p. 23), was first of all an Augustinian cleric who, according to himself, was assisting the Andean communities in their conversions to the Christian belief. In this regard and after witnessing "superstitions" he informed the hosting communities about their "wrong-doing" and continuously reported cases of "idolatry" to the colonial authorities to intervene, as he proudly mentions in his work. ${ }^{12}$ Unlike the previously mentioned modern anthropologists, Ramos Gavilán was happy when reporting that (at least in Copacabana)

\footnotetext{
11 In the consulted article, the author abstains from openly normative judging; however, as a reader, it is easy to recognize that she is unhappy with the changes when writing that the described relationship "was decisively broken" (Allen 2016, p. 342).

12 Taking into consideration what such interventions could mean for the "wrongdoers" in colonial times, the reported rapid indigenous explanation of their behaviors as having nothing to do with rites is more than understandable.
} 
most people were finally giving up reciprocal rituality with their ancestral divinities and embracing Christian doctrine.

Recent studies, however, suggest that neither coloniality nor modernity ended the reciprocal relationalities between and beyond humans in the Andes, but that they continue to shape, in transformed ways, (inter-)actions of indigenous populations in urban centers that are also active in international and transoceanic trade (e.g. Tassi 2016). All my interviewees reported that they engage in the car blessing rituals in order to achieve protection from accidents and incidents when driving, "to avoid accidents, problems with the car or, in my case, the motorbike", "so nothing happens to nobody of us in the family, [to] the mobility when you are driving, so there is no accident", "so the motor engine does not break down". For $\mathrm{T}^{*}$, the blessing rituals are to be understood as an insurance: "When we buy a mobility, we also buy an insurance. We get it blessed, therefore the mobility works well. That is the insurance". Despite him engaging in blessing rituals, A*'s car was nevertheless involved in a traffic accident while his son was driving, what caused $A^{*}$ to further reflect on the power of the blessing: "Even though he [the son/the car] crashed, it may be that it was with luck [suerte], right? Because it could have been worse, there is always this probability. Therefore, even though complaining, one finishes saying, well, there was no personal injury, only damaged steel. Even though the steel costs and it was many years of savings and so forth, it is [only] the steel".

While surely being an important one, the protection while driving is only one of the reasons why the interviewed drivers engage in blessings. While explaining the relevance of different performed rituals, they all referred to rituals that are not linked to traffic and transport in order to link themselves to what they perceived as the majority of Bolivians' and Catholics' (reciprocal) behaviors. References count from blessing rituals done for businesses, buildings, mines, animals, fields (of farming and urban use), construction sites and love relations. The professional drivers recount how with their car blessings they also look forward to greater economic success. The mechanic $\mathrm{T}^{*}$ reports that he asks for "wisdom [sabiduría]" to keep up-to-date while engaging with always more complicated automobile technologies. $\mathrm{R}^{*}$ and $\mathrm{F}^{*}$ ask for more passengers:

When you are doing a k'oa for a business or shop [negocio o tienda], you ask for more clients. And they come. Now, I myself, when I do a k'oa, I ask for more passengers. And there are more!

I: If you do not do a $k$ 'oa, will there be fewer?

That, I do not know. That is... I believe... maybe fewer, maybe more. I don't know this.

I: It is to be tried?

Not by me. Because I have believed in these things from when I was small, I just have to continue doing so. I even have to teach these things to my sons.

All interviews suggest that drivers in contemporary Bolivia continue experiencing a positive reciprocity in their rituals, which they do not only use to ask for future protection and well-being, but also as thanksgivings for already received divine/ 
worldly attention. ${ }^{13}$ However, the difficulty that $\mathrm{F}^{*}$ faces while answering my follow-up question on the antipodal case manifests that changes are occurring among the drivers who are not all that certain anymore, to what degree not engaging in the rituals might also result in divine/worldly reactions. $F^{*}$ reports that the taxi syndicate he joined did not engage in blessing rituals in the first two years of its existence "and there were many accidents happening. There were many accidents and because we did not do a k'oa that is why they are happening, they said. Was it because of that or was it not? I do not know now. [...] The elders, who know already more, they say: We did not do a $k^{\prime} o a$, that is why the accidents are happening. They think that way. But it has to be seen too, right? It has to be examined, it also has to be seen why".

While not being sure if there might be a causal relation between insufficient blessing rituals and accidents, $\mathrm{F}^{*}$ as well as most interview partners reportedly intensified, after suffering misfortunes, their personal blessing rituals for preventive reasons: "Maybe She needs it", "the feeling stays something I did not do well. The bendición was not sufficient. Maybe I was acting miserly and I did not do what I had to do additionally, the k'oa", "I'm not doing them [regularly enough], and I feel that my car is truly breaking down". While G* reports "I do not believe that any Deity, one could say so, right?, is mean and takes something away from you. I do not believe that this exists or happens. If you are a devotee, She will always be in your favor" and also $\mathrm{R}^{*}$ reflecting on a past accident says that "If I crashed at a place, in a curve, it is not because the Earth is reclaiming something from me at this place [lugarcito], but because I was inattentive with myself. [...] God will not tell you, you are condemned, you are dying in this curve. Never will God tell you this", $\mathrm{S}^{*}$ is convinced that worldly/divine beings react if not satisfied with the attention received: "She is punishing them, something happens. If you do not believe in the Virgin, She punishes them, secretly, without warning them. And they do not know why these things are happening to them. They say... Some continue to say that no, it happened because of some [logical] thing. They still do not believe in the Virgin. The Virgin punishes. Without warning, from one moment to another. And the people are not believing why She is doing this accident or anything that happens. It comes from not believing in the Virgin. It is the Mother Earth doing her punishment". To prove his statement, $\mathrm{S}^{*}$ continues giving different examples when he suffered from negative effects of this reciprocal relation, once while catching some condition relating to his arm, supposedly because he was too lazy in his offerings, which only went away when he went to the church services more regularly.

Positive and, to a certain degree for many drivers, also negative effects experienced in their lives falsify the still in some studies reproduced hypothesis that the reciprocal rituality is generally abandoned by persons identifying with and acting as moderns. When asked at the end of the interviews about a potential disappearance of the described rituals, all interviewees responded that the rituals are not disappearing (except $\mathrm{A}^{*}$ who argues that in the urban centers the rituals are lost in the public spaces and redefined only in private spheres). Most responded that the ritual practices are actually intensifying, giving different explanations, including that better

13 "The ch'alla has this meaning of thankfulness, of retributing for what we receive due to the gloriosity [sic!] and benediction of God, of the Earth producing for us". 
roads result in more and easier pilgrimages, that faster traffic calls for more protection (driving is more dangerous than riding or walking), and that due to an increase in technology there are more "things to be thankful for".

While asked, at the end of our interview, for an explanation about the identity of this Pachamama ${ }^{14}$ that he referred to a lot, $\mathrm{T}^{*}$ reveals the intimacy of this reciprocal relation he maintains:

What more could I tell you now? The only thing [I still have to say is], that now I am already prepared to offer here the ch'alla of the Tuesday of ch'alla $^{15}$ [...], so it goes well and this garage takes a good path [se encamine bien].

I: Maybe you could still explain how... a bit about who the Pachamama is? Because there, they do not offer, they do not know well.

Well, the Pachamama is the Virgin that is in the Earth. And the Virgin is the Mother Earth. The one that gives to you. I commented that in this place where I work, the Virgin exists here for me, right? And this Virgin is the one that asks me for things and I give to Her. [...] I often offer Her because sometimes the work is diminishing and I offer her any month [in addition to preset dates for ch'allas in August and for Carnival]. That is then an initiative by myself. Maybe She needs it and I go and I buy it, I voluntarily go. Sometimes I do it alone, I do not have to be with anybody. That is the Pachamama who asks you. If She does not give you work, it is because She too needs it. Therefore, I go and I try to buy the k'oa the way it is. I do offer Her with a cigar, as I told you before, right? [...] That is what I do if work is lacking. Well, that is everything I can tell you... Another thing I can tell you [is] that every house, for example the neighboring one here, also does this. But that is also not the same anymore, they do also have their Pachamama there, She is in every place. They are acting equally, one time I noticed the smell of k'oa there. They are doing a $k^{\prime} o a$, so I will also do one, I said. That's it. I do not know what more to tell you.

The attentive reader might have noticed throughout my article a constant intermixing of different names of divine/worldly addressees in the direct quotations. This reflects their appearance in the narrations of most of my interviewees in which I did not interfere in that regard till the very end of our conversations. Reflecting the structure of my interviews, the last pages of this article however shall also serve to exactly analyze these patterns.

\section{Andino-Catholic Syncretism}

Syncretism was and is a frequently used term in theology and religious studies; however, it is also problematic, as it was used intrinsically linked to pejorative claims about "authenticity" of religious traditions for a long time. "Syncretism" was

\footnotetext{
14 In academic research, Pachamama normally is translated as „Mother of Space/Time “, for a contemporary theological discussion, consult, e.g., Titizano (2017).

15 Tuesday of the Carnival's week (28.02.2017).
} 
therefore first of all a tool of an anti-syncretistic agenda, used either by ritual elites who want to disentangle "true from false" parts in a religious tradition, or anthropologists trying to identify and "save" seemingly decomposing identities and cultures of a past. These understandings, however, differ largely from the term as it was initially introduced by Plutarch who defined syncretism ( $\sigma 0 \gamma \kappa \rho \eta \tau \imath \sigma \mu o ́ s)$ as an emic Cretan concept to describe practices of unifying across internal differences for the purpose of military defense (Plut. de frat. am. 490B).

Contemporary research in religious studies, partly also relying on the changes in the Catholic doctrine about missionary activity introduced by the Second Vatican Council (1962-1965), tries to redefine the term syncretism as a non-normative analytical tool, arguing that it is helpful to understand religious entanglements beyond the actions of mere individuals (as identified under the term bricolage). However, it continues to be widely discussed in missiology to what extend syncretism (and inculturation) are valid practices of missionary activity without them undermining the religious system to be promoted. In some geographical contexts, e.g. Latin America and the Caribbean, syncretism constitutes a more accepted part of the theological discourse than in others, where it continues to be rather a taboo. ${ }^{16}$ Rosalind Shaw and Charles Stewart (1994) envisioned syncretism research to describe processes and discourses instead of categorizing religious "products":

Simply identifying a ritual or tradition as 'syncretic' tells us very little and gets us practically nowhere, since all religions have composite origins and are continually reconstructed through ongoing processes of synthesis and erasure. Thus rather than treating syncretism as a category [...], we wish to focus upon processes of religious synthesis and upon discourses of syncretism (Shaw and Stewart 1994, p. 6).

Together with her informants in rural La Paz, Ina Rösing (2001) constructs a model to explain patterns of andino-catholic syncretism performed by Quechua speakers at the beginning of the twenty-first century. She interviews twelve indigenous Catholic catechists with three initial questions about whether they perform sacrificial rituals at "Andean shrines", whether there is a risk that different ritual addressees might become "envious" of each other and what they (as religious elites) advise her (as a Catholic layperson) to respond to criticism from an (invented) priest who disregards her offerings as "pagan". ${ }^{17}$ According to Rösing, all her interviewees experience theological contradictions between Catholic and Andean religion; however, they cope with different strategies (shifts in the frames of references, partition of areas of activity, general license, encryption and a hermetical formula) to bypass these contradictions individually and collectively. Before identifying a new explanation where religious synthesis is happening, I will discuss Rösing's model using my data.

My interviewees did not perform partitions regarding areas of activities to the same degree as the informants of Rösing did, who identified God to be in charge of

\footnotetext{
${ }^{16}$ For a discussion of syncretism in German missiology, consult, e.g., Bünker et al. (2010).

17 I would agree with the criticism that her questions are not ideally framed regarding a value-free position an interviewer should try to uphold in the conversation; however, in my opinion, they are open enough that her model does not lose any of its validity because of her suboptimal questioning.
} 
mercy and forgiveness, while the Andean ritual addressees are said to be approached for day-to-day well-being (Rösing 2001, p. 54-57). In contrary, when asked about differences between the ch'alla and the bendicion, $\mathrm{F}^{*}$ united the two rituals that he described before using different names and procedures:

I see them equally. Because equally in both you are asking with faith. You are asking with faith at both of them. Despite the fact that they look different, right? But not to me. Because, look, at that moment when the Father is giving it [the car] the bendicion, there are also other persons who are fumigating it, who are giving it a k'oa. I believe the two together as one give more protection.

Despite not identifying different areas of responsibility for different ritual addresses, but counting on their simultaneous assistance while being on the road, all interviewees (except $\mathrm{A}^{*}$ ) engage more often in $k^{\prime}$ oas and ch'allas than in bendiciones and mention in their narrations the name of God rather rarely, while mostly referring to the Virgin Mary, Mother Earth or Pachamama and different Saints. R* explains their importance referring to an invisibility of God:

We cannot see God, right? However, the human beings we need to see, to see what it was for, right? But that is bad, but that is how we move. It should not be like that, right? The faith is... You have faith because you believe in something you cannot see. Because if you see it, you can palpate it and it is no longer faith, right? You are convinced, right? But no, the human beings we need, we are weak in that aspect and we need intermediaries sometimes to reach God.

$\mathrm{R}^{*}$, who had worked for the Catholic church for six years before starting to drive his bus and was exposed far more than the other drivers to anti-syncretistic discourses, does include God as a ritual addressee of the k'oa, differing in that regard from all other interviewees who in case they identified a ritual addressee other than the cars themselves identified it exclusively in the figures of the Virgin Mary, Mother Earth or the Pachamama. Not so $\mathrm{R}^{*}$, who reflects on the addressees of the $k$ 'oa while putting a lot of caution to denominate his interacting with healers in an acceptable way for a Catholic orthodoxy:

What is it that God receives? It is the smoke, the essence, that is what we are offering and the rest stays for the Virgin Pachamama, for the Earth, it becomes ashes. That's it. That is how the whole ritual is done. And we do have... There are persons... For example, when you want to do the ch'alla, I do have to search a person... how can it be said... somebody who directs, right? Who raises his orations, he knows his own orations, his own words and he asks for it on your behalf [te lo pide el], on his knees he asks the Earth for forgiveness because sometimes we are exploiting Her, right?

All my interview partners identified as Catholics and $\mathrm{S}^{*}$ was proud to promulgate that "in the first place, one has to always obey the Virgin". The shift in the frames of reference to legitimate their offerings mentioned by Rösing is that her interviewees stated they stopped performing rituals to harm enemies and that therefore God surely 
will pardon them their continuative performance of rituals for well-being (while admitting that it might be dangerous to obligate Him to share his place with nonChristian divinities). Similar arguments are mentioned throughout my interviews, when drivers tried to distance themselves from bad blessing practices "I am going to get a blessing on this weapon, this knife to kill people, that is bad", "there are things of God and there are things of the Devil", "who is not against me, is with me, says God", "directed to God, not against God, not as a satanism". However, while expressing a certain uneasiness regarding co-drivers who are said to put dead frogs as lucky charms in their glove compartments, the shift in the frame of reference is, first of all, made towards the evangelist movements who are very successful in the acquisition of new members in contemporary Bolivia but who, according to many of my interview partners, are to be mistrusted, as for example expressed by $\mathrm{S}^{*}$ :

We are always fumigating, always. We are always doing everything. We believe in the Saints [santitos], we are doing this. This is sacred, we are not going to forget it. It is difficult to forget it.

I: What for? Why forgetting?

Yes, why forgetting, right? There are people who change, they turn over to the other side, they become... what was it?... evangelists. These, they do not believe in the Saints. But from my side, we are never going to permit this. There are people who do not believe. They say and you are worshipping this, that is what they say to us. There are people who are against the Saints. Ourselves, however, we are not doing this. Always as we are Catholics, we will always continue to be Catholics.

According to $\mathrm{S}^{*}$, the evangelists continually try to seduce him by talking "nicely [bonito]"; however, he stays alert, because "they who do not believe, for what reason might they be that way? We do not know their intentions. [...] We Catholics are always seconding the Virgin, the Mother Earth. Always. Always with Her. We parted from the Earth and we also have to return into the Earth. We cannot divert ourselves from this".

Many of the interview partners do not see any tension between Catholicism and ritual offerings and explain the rejection they experience from some parts of the Catholic clergy (who in Bolivia continue to be to a large part foreigners) in the fact that these dislike alcoholic beverages, "the clerics [curitas] do not drink", "drinking shots and drinks, obviously the Father [padrecito] will never like this. Only very little wine and nothing more". The motorcyclist $\mathrm{G}^{*}$, however, who has already been to Europe, segregates the rituals into parallel religious systems. After enouncing that "we are good Catholics and good lovers of the Earth", G* goes on explaining: "This one [bendición] is something that is to be respected and afterwards the other [ch'alla] is also to be respected. Now the Fathers [padrecitos], the clerics [curitas], according to their religion, according to the religion it is like something obscure maybe, something outside their norms, their beliefs [creencias], right? And they won't approve of it, but they cannot go against the people either, right?".

In the presented cases, religious synthesis in personal theological reflections of drivers seems to be first of all a consequence (rather than a cause) of exposure to anti-syncretistic positioning inside and beyond the Catholic clergy. Most drivers 
who did not experience such anti-syncretistic positions to a larger degree, while still not inviting clerics to the personal blessing rituals, also don't necessarily attribute a lot of meaning to their absence. One could therefore argue that they are not performing or engaging in syncretism. Bus driver $\mathrm{R}^{*}$, who himself supposedly experienced anti-syncretism (and probably also syncretism) at different stages during his work for the church (and abandoned the planned path to become a priest only to get married and have children), performs clearly syncretism when narrating the different car blessing rituals to me. According to him, the main difference between his rituals does not lie on the side of their addressees but in the origins of its written or unwritten legitimation:

God says who is not against me is with me, says God, right? Therefore, the ch'alla does not mean, does not want to say that I do not believe in God, it does not want to say that I am a... how to tell you... an antichrist. No. It has to be respected. The ch'alla has this traditional sense. It is not by an intellectual sense, rational, no. It goes more by a sense of the feeling [sentido del sentimiento]. The feeling of the human person makes that it has this gest of the ch'alla. Therefore, I cannot judge intellectually, I cannot judge that this is not permitted, because it is not in the dictionary, because it is not in the Bible, it does not say so. No. There is nothing written about it.

According to him, the priests who claim theological problems with the ch'alla are relying themselves too heavily on written sources and that therefore "it [the human feeling] does not enter their capacities as intellectuals. [...] That is why many [of the clerics] do not take part, do not like to orientate, because they feel that it is bad. But no. It is not bad. If we are acting with wisdom and with the heart, with the reason and with the heart, we can design the things right and separate what is good and what is bad".

$\mathrm{R}^{*}$ is not the only one of the interviewees who refers to internal feelings when explaining the need to engage in blessing rituals; however, unlike the other ones, he does not make the bendición dependent on these feelings, but states that this has rather a "more biblical sense, yes, more evangelical". $F^{*}$ nevertheless states, regarding all of the rituals he engages in: "It is born to us from inside and it goes well for us [nos nace de adentro y nos va bien]. When you are believing more, it goes well for you, but you have to believe. For these things, if you are going to do these things, it has to be born from you, you have to believe. Because some say, no, nothing happens, I do not believe in these things, but that is already their... it depends on oneself. If you believe, you are doing well, if not, I do not know how it would be, but I believe. I believe in these things".

Among the interviewed drivers, different degrees of territorialization of the ritual addressees can be identified, some arguing that they, especially the Pachamama, are localized at particular places in the landscapes, while others claim that these worldly/divine entities including the Mother Earth are to be understood in a universally valid, deterritorialized way. However, they agree on their ultimate goal of living well, regarding which $\mathrm{R}^{*}$ clearly reunites the different ritual specialists: "I do want God to benedict this [bus] for me through the priest [sacerdote], through the cleric [cura], through the [healing] persons. That he benedicts this instrument, this 
working tool, that God benedicts it with the element of water that we are using, so no disgrace happens to me, so it does not ruin itself, so I care for it and work caring. And through this working tool, I take the daily bread, right? He Himself. Everything is for the daily sustenance. Everything is for the good life [vivir bien]. All the cultural religious manifestations that we are doing, everything is mixed together, everything is around the good life. There is no other motivation, there is no other sense".

\section{Conclusion}

This article explored car blessing rituals performed by drivers from Chuquisaca. It showed that Bolivian drivers distinguish between three rituals (ch'alla, k'oa, bendición) that are all performed in order to obtain divine/worldly protection when on the road. While two of them (ch'alla, k'oa) get closer linked together and either performed by the drivers themselves or by hired professional healers (curanderos), the third (bendición) is exclusively done by Catholic clerics and combined with at least one annual motorized pilgrimage. However, many drivers do not consider this third ritual to be successfully concluded until it is completed with an additional ch'alla. The article showed that despite ongoing views in missionary activity and anthropology that propose an immediate end to ritual offerings and subjacent logics of reciprocity while engaging with divine/worldly addressees, these rituals are continuously performed in urban and "modern" contexts. Without any doubt, animals as transport workers are increasingly replaced by motorized vehicles; however, the rituals ensuring their well-being are not abandoned but transferred to the new form of mobility, the cars. The rituals are considered to be of high importance for safe driving (and economic successes while working as a professional driver); however, this does not signify that other more "secular" safety measures are not considered additionally (several interviewees mentioned the importance of wearing seatbelts).

Most interviewed drivers did not theologically distinguish between the blessing rituals, their difference in naming was first of all explained with different ritual ingredients. The negative attitude towards some of the rituals by parts of the Catholic Church was therefore explained first of all as a criticism of alcohol which is attributed to the Catholic elites. Also, evangelical positionings that are more visibly engaging in challenging the rituals are first of all explained with criticism of alcohol. Alcohol, however, is considered by the interviewed drivers to be essential for a successful performance of the rituals as it enables the performer to take active control over their outcome. The interviewed drivers agreed on a positive reciprocity in the sense that performed rituals increase their safety and well-being; however, they disagreed as to what extend rituals not performed trigger direct worldly/divine reactions. While some interviewees are convinced that the ritual addressees are never going to punish insufficient offerings, others do experience misfortunes linked to divine/ worldly reactions, which only end when the ritual attendance is increased and balanced out again. Most drivers, however, are personally not so certain about the link between personal misfortunes and divine/worldly vis-à-vis, but do still increase their offerings in the aftermath of problems for prophylactical reasons. 
All interviewed drivers identify as Catholics and explained all their ritual offerings as necessary parts of the Catholic faith. Only the ones who were exposed to anti-syncretistic discourses in and beyond the Catholic Church engaged themselves in different arguments that we could classify as religious synthesis. However, these arguments are first of all to be understood as a reaction to anti-syncretism, therefore rather than as syncretism they should be understood as practices of anti-anti-syncretism. By identifying all ritual offerings as necessary parts of the Catholic faith, the interviewed drivers differ from the main theological discourse of the Catholic Church in Bolivia as presented by an interviewed theologian from Santiago de Chile who perceived the offerings (even including, to a large part, the bendición) as independent of the Catholic Church while however admiring them as profound religious feelings that he contrasts with secularism (identified by him as the main problem of modernity). "Cults [cultos] to natural beings", according to him, are no problem for Christian religion because while venerating the products of God's glory indigenous people are "indirectly" venerating God who he classifies as the omnipotent beginning of everything alive. Nevertheless, he does not show any interest in participating himself in the rituals, explaining that he is centered in the "category" of God. This theological position, even while performing inculturation, differs from the religious synthesis of many interviewed drivers because it segregates the ritual offerings into different systems of belief that at the end are classified as equally valid, nevertheless as not necessary parts of the same religion. Therefore, one could conclude that syncretism in contemporary Bolivia, while certainly also being part of an institutionalized discourse, is first of all a process of countering anti-syncretistic agendas from below.

\section{Declarations}

Conflict of interest The author declares no competing interests.

Open Access This article is licensed under a Creative Commons Attribution 4.0 International License, which permits use, sharing, adaptation, distribution and reproduction in any medium or format, as long as you give appropriate credit to the original author(s) and the source, provide a link to the Creative Commons licence, and indicate if changes were made. The images or other third party material in this article are included in the article's Creative Commons licence, unless indicated otherwise in a credit line to the material. If material is not included in the article's Creative Commons licence and your intended use is not permitted by statutory regulation or exceeds the permitted use, you will need to obtain permission directly from the copyright holder. To view a copy of this licence, visit http://creativecommons.org/licen ses/by/4.0/.

\section{References}

Adey P, Bissell D, Hannam K, Merriman P, Sheller M (eds) (2014) The Routledge Handbook of Mobilities. Routledge, London

Alberti G, Mayer E (eds) (1974) Reciprocidad e intercambio en los Andes peruanos. Inst. de Estudios Peruanos

Allen CJ (2012) The hold life has. Coca and cultural identity in an Andean community, 2nd edn. Smithsonian, Washington 
Allen CJ (2016) Stones Who Love Me. Dimensionality, Enclosure and Petrification in Andean Culture. Archives de sciences sociales des religions 61(174):327-346

Bastien JW (1985) Mountain of the condor. Metaphor and ritual in an Andean Ayllu, 2nd edn. Waveland, Long Grove

Böhm S, Campbell J, Land C, Paterson M (eds) (2006) Against Automobility. Blackwell Publishing, Malden

Bünker A, Mundanjohl E, Weckel L, Suermann T (eds) (2010) Gerechtigkeit und Pfingsten. Viele Christentümer und die Aufgabe einer Missionswissenschaft. Matthias-Grünewald, Ostfildern

Cajka PS (2010) Riding with St. Paul in the Passenger Side. The Archdiocese of Milwaukee Enters the Automobile Age, 1920-1965. American Catholic Studies, 121(2):65-93. https://www.jstor.org/stable/44195277. Accessed 02 March 2021

Dant T (2004) The Driver-car. Theory Cult Soc 21:61-79. https://doi.org/10.1177/0263276404046061

de la Cadena M (2015) Earth Beings. Ecologies of Practice across Andean Worlds. Duke University Press, Durham

Elias JJ (2011) Wings of Diesel. Trucks, identity and culture in Pakistan. Oneworld, Oxford

Ferraro E (2004) Reciprocidad, don y deuda. Relaciones y formas de intercambio en los Andes ecuatorianos. Quito, Abya-Yala

Giucci G (2012) The cultural life of the automobile. Roads to modernity. Translated by Mayagoitia A and Nagao D. Austin, University of Texas Press

Glaser BG, Strauss AL (2009) The discovery of grounded theory. Strategies for qualitative research, 4th edn. New Brunswick, Aldine

Gose P (1994) Deathly waters and hungry mountains. Agrarian ritual and class formation in an Andean town. University of Toronto Press, Toronto

Lazcano González R (2017) Notas al hilo de la lectura. Historia de Nuestra Señora de Copacabana, del agustino Alonso Ramos Gavilán (1570-1621), edición de Hans van den Berg y Andrés Eichmann (Sucre, 2015). Archivo Agustiniano 101(219):253-260

Lefebvre H (1971) Everyday Life in the Modern World. Harper \& Row, New York

Mauss M (2002) Essai sur le don. Forme et raison de l'échange dans les sociétés archaïques. Digitalized by Jean-Marie Tremblay. Chicoutimi, Les classiques des sciences sociales

Mayer E (2004) Casa, chacra y dinero. Lima, Inst. de Estudios Peruanos, Economías domésticas en los Andes

McLuhan M (1994) Understanding media. Cambridge, MIT Press, The extensions of man

Miller D (2001) Driven societies. In: Miller D (ed) Car cultures. Berg, Oxford, pp 1-34

Montes Ruiz F (1999) La máscara de Piedra. Simbolismo y personalidad aymaras en la historia, 2nd edn. Editorial Armonía, La Paz

Mostowlansky T (2017) Azan on the Moon. Entangling Modernity Along Tajikistan's Pamir Highway. University of Pittsburgh Press, Pittsburgh

Nigam A (2011) Desire named development. Penguin Books, New Delhi

Ødegaard CV (2011) Sources of danger and prosperity in the Peruvian Andes. Mobility in a powerful landscape. J Royal Anthropological Institute 17(2):339-355. https://doi.org/10.1111/j.1467-9655. 2011.01683.x

Platt T (2016) Estado boliviano y ayllu andino. Tierra y tributo en el Norte de Potosí, 3rd edn. Centro de Investigaciones Sociales, La Paz

Plutarch (1962) Plutarch's Moralia in Fifteen Volumes. Volume VI. 439A-523B. With an English translation by Helmbold WC. London, William Heinemann

Ramos Gavilán A (1621) Historia del célebre santuario de Nuestra Señora de Copacabana y sus Milagros, e Invención de la Cruz de Carabuco. Lima, Jerónimo de Contreras. https://archive.org/details/ historiadelceleb00ramo

Rockefeller SA (2010) Starting from Quirpini. The travels and places of a Bolivian people. Bloomington, Indiana University Press

Rösing I (2001) Die heidnischen Katholiken und das Vaterunser im Rückwärtsgang. Zum Verhältnis von Christentum und Andenreligion. Winter, Heidelberg

Ryburn M (2018) Uncertain citizenship. Everyday practices of Bolivian migrants in Chile. University of California Press, Oakland

Sachs W (1992) For love of the automobile. Looking back into the history of our desires. Translated by Reneau D. Berkeley, University of California Press

Salles-Reese V (1997) From Viracocha to the Virgin of Copacabana. Representation of the Sacred at Lake Titicaca. University of Texas Press, Austin 
Sallnow MJ (1987) Pilgrims of the Andes. Regional cults in Cusco, Washington, Smithsonian

Shaw R, Stewart C (1994) Introduction. Problematizing syncretism. In: Stewart C, Shaw R (eds) Syncretism/anti-syncretism. The politics of religious. London, Routledge, pp. 1-24

Stewart, Charles; Shaw, Rosalind (eds.) (1994): Syncretism/anti-syncretism. The politics of religious synthesis. London, New York: Routledge (European Association of Social Anthropologists). ISBN-10: $0-415-11116-1$

Tassi N (2016) The native world-system. An ethnography of Bolivian Aymara traders in the global economy. Oxford University Press, Oxford

Taussig MT (2010) The devil and commodity fetishism in South America, 30th edn. University of North Carolina Press, Chapel Hill

Titizano C (2017) Mama Pacha. Creator and Sustainer Spirit of God. Horizontes Decoloniales / Decolonial Horizons 3:127-159. https://doi.org/10.13169/decohori.3.0127

Upton RL (2016) Negotiating work, family, and identity among long-haul Christian truck drivers. What would Jesus haul? Lanham Lexington

Urry J (2000) Sociology beyond societies. Mobilities for the twenty-first century, London, Routledge

Urry J (2004) The 'System' of Automobility. Theory Cult Soc 21:25-39. https://doi.org/10.1177/02632 76404046059

van den Berg H (2015) Introducción. In: van den Berg H, Eichmann Oehrli A (eds) Alonso Ramos Gavilán. Historia del célebre santuario de Nuestra Señora de Copacabana, y sus milagros, e invención de la Cruz de Carabuco. Sucre, ABNB, pp. 17-64

Publisher's Note Springer Nature remains neutral with regard to jurisdictional claims in published maps and institutional affiliations. 